\title{
Student Perceptions Of The Value Of Internships In Business Education
}

\author{
Michael Hergert, San Diego State University, USA
}

\begin{abstract}
Internships are an increasingly popular element of higher education in business and provide many potential benefits to students. An internship experience can help students make the connection between their academic studies and the world of business. They can also create valuable connections and networking opportunities to improve the employment and career prospects for students. This study analyzes the internships of 114 undergraduate and graduate students to determine what factors account for the most valuable internship experience. The results show a strong statistical correlation between the perceived value of the internship and the student's demographic profile, the structure of the internship, and the connection to the students' career plans. These findings provide a basis for designing successful internship programs in business education.
\end{abstract}

Keywords: Internships, Business Education

\section{INTRODUCTION}

nternships have become a standard feature in American business schools. Studies suggest that the vast majority of business schools offer internships as a component of the curriculum (Maskooki, Rama, and Raghunanda, 1998; Rothman, 2007). The Association to Advance Collegiate Schools of Business (AACSB) has recommended that business schools more tightly link their programs to the business world and cites internships as one mechanism for accomplishing this goal. However, there is significant variation in the ways in which internship programs are implemented (Coco, 2000). Although somewhat rare, some business programs require an internship for graduation. In some schools, academic credit is given for internship programs, while others do not. Even if academic credit is granted, large differences exist in the way this is done. In some cases, a letter from a supervisor certifying the completion of a specified number of hours is all that is required. Most schools require at least a final report or student journal to document the experience. In some schools, academic credit for the internship is done through a highly structured format that is tightly integrated into the rest of the student's program. This study will attempt to sort out which factors seem to play the strongest role in creating a valuable internship experience for students.

Prior research has generally supported the value of student internships. Internships can play an important role in helping students make good career choices (Brooks et al, 1995). They also provide an opportunity to learn specific job related skills that are not taught in traditional business programs (Garavan and Murphy, 2001). Some benefits of internships may persist well beyond graduation. Studies have shown that students who participated in an internship have greater job stability in their early careers (Richards, 1984) and higher job satisfaction (Gault et al, 2000). Other studies have found that internships can make students more ambitious (Pedro, 1984) and can help ease the transition from school to work (Paulson and Baker, 1999). Students are often motivated to seek out internships as a means for securing eventual permanent employment. Prior research indicates that this does indeed work (Callanan and Benzing, 2004; Knouse et al, 1999).

While there is ample evidence on the practical benefits of internships, there has been less research into the exact role internships play in the teaching of business. Early research into learning theory has highlighted the importance of teaching students how to apply the knowledge and concepts they have acquired through previous coursework (Bloom, 1956). However, there has been significant criticism of the effectiveness of business schools in 
reaching this goal. Candy and Crebert (1991) argue that business students are well-versed in theories and knowledge, but lack the ability to solve business problems. The seminal study by Porter and McKibbin (1988) concluded that business programs are too narrow and disconnected from the real world of business. Some of this problem has been attributed to a perceived disconnect between the abstract and theoretical bias of business schools and the pragmatic needs of the business world (Angelidis et al, 2004). It cannot be assumed that students will independently make the connections between theory and practice. The use of case studies and simulations are useful techniques in helping students learn how to apply theories and models to business situations. Internships take this approach one step further. The business world becomes a laboratory for students to see how the material they have learned in the classroom relates to the practice of business. In this study, the internship experiences of students are analyzed to determine what factors seem to create the greatest perceived value.

\section{HYPOTHESES AND DATA}

In order to gather data on the value of the internship experience, a survey was administered to 114 business students at a large public university in the southwestern United States. Approximately $75 \%$ of the students were undergraduates and the remainder were pursuing a graduate degree. The survey was administered during the semester following the completion of the internship. Over half of the students had graduated and begun working full time when they completed the survey instrument. The survey focused on the perceived value of the internship experience. Students were asked to rate the value of their internship from 1 through 5 on a Likert scale, where $1=$ Internship was of very little value and 5= Internship was extremely valuable. The mean score for this variable was 4.1 , indicating that students generally perceived their internship experience as being very valuable.

Students were also asked to compare their internship experience to traditional coursework. On a five point scale where 1= Much Less, 3= Same, and 5=Much More, students reported that the difficulty (mean score of 2.9) and workload (2.9) for the internship was approximately equal to a regular class. However, their motivation (3.9) and level of interest (3.8) were significantly higher (at a 95\% confidence level) than for a traditional course. They also reported much higher career value (4.0) and practical value (4.4) for the internship in comparison to regular classes. Both of these differences were significant at the $95 \%$ confidence level.

It was apparent from the survey that students found their internships valuable. Further investigation was conducted to identify the factors which create the most effective experience. The data was organized into the following groups:

Demographics. Data was collected on AGE, GENDER, YEAR in SCHOOL, and GPA. Prior research has indicated that older students generally receive greater benefit from internships due to their greater maturity and preparation for the workplace. (Knemeyer and Murphy, 2002). There is also evidence that students with higher GPA's are more likely to pursue an internship (Callanan and Benzing, 2004), although it is unclear whether or not they benefit to a greater extent.

Format/Pedagogy. The internships in this study varied in format. Most of the students received credit for their internship, but some did not. The internships varied in number of hours worked and whether or not students were paid for their work. Data was collected on PAY and CREDIT as dummy variables $(0,1)$. Students were also asked how many hours per week they worked (HOURS). There was also variation in the extent to which the internship was part of a formal class. In some cases, the internship was an informal experience with little or no specific requirements. In others, the internship was done through a course with highly structured requirements. Students were asked to rate their internship on a five point scale on the extent to which their internships were structured $(1=$ Not at all, 5= Highly structured). Finally, students were asked about the extent to which the internship was integrated into their academic program (1=Not at all, $5=$ Very Integrated). This variable was intended to address the issue raised by Bloom in making the connection between the classroom and workplace.

Career Orientation. The last set of variables measured the value of the internship to student career plans. Students were asked how close the internship was to their ideal long term career job (PROXIMITY) and on the level of interest they had in the specific tasks involved (INTEREST). Students were also asked how useful the internship was in helping them find a job (JOB FIND). 
The first stage of analysis was to correlate the descriptive variables with the perceived value of the internship. The results are shown as Table 1.

Table 1

Correlations Between Perceived Value And Explanatory Variables

VALUE

\begin{tabular}{ll}
\hline AGE & $.548^{* *}$ \\
GENDER & .057 \\
LEVEL & $.491^{* *}$ \\
INTEREST & $.666^{* *}$ \\
HOURS & $.577^{* *}$ \\
PROXIMITY & $.460^{* *}$ \\
JOB FIND & $.785^{* *}$ \\
CREDIT & $.262^{* *}$ \\
STRUCTURE & $.210^{* *}$ \\
INTEGRATION & $.583^{* *}$ \\
GPA & $.536^{* *}$ \\
PAY & $.276^{* *}$ \\
\hline
\end{tabular}

** significant at the $95 \%$ confidence level

The results in Table 1 are striking. With the exception of gender, every variable tested was significantly correlated with the perceived value of internships. It appears that older students (whether measured by age or grade level in college) do perceive greater benefit from internships. This seems to reflect greater maturity and ability to deal with ambiguity. It also appears that students with higher GPA's perceive greater value from internships. They may be better able to make the cognitive connections between what they have learned in class and what they are experiencing in the workplace. Students also seem to appreciate compensation for their internships, whether it takes the form of pay or course credit, although these variables are not as strongly correlated with perceived value as some of the others. For example, the variables relating to career development are extremely strong. The highest perceived value came from internships that lead to finding a job. The correlations are also strong for internships that are close to career goals and interests. The pedagogical variables were also significant. Students seem to get greater value from internships that have a specific structure and are integrated into the program of study.

In order to better understand the relationships between these variables, the data was combined into a multivariate regression model. A series of stepwise regressions was run using perceived value (VALUE) as the dependent variable and the remainder of the data set as independent variables. A typical result is shown as Table 2.

Table 2

Regression Model for Perceived Value

\begin{tabular}{lccc}
\hline Dependent Variable: VALUE & \multicolumn{3}{c}{ Significance } \\
\hline Independent Variables & Coefficient & t Statistic & .000 \\
\hline CONSTANT & -9.718 & 5.95 & .000 \\
JOB FIND & .447 & 5.31 & .000 \\
AGE & .279 & 4.94 & .001 \\
GPA & 1.369 & 3.34 & .003 \\
INTEREST & .263 & 3.05 &
\end{tabular}

Adjusted R Squared .61

When combined into a multivariate model, the most important variables seem to reflect student demographics (AGE and GPA) and career development (JOB FIND and INTEREST). These four factors account for approximately $60 \%$ of the variation in perceived value of internship experiences. 


\section{CONCLUSION}

Internships are an important part of the business school curriculum. They play a crucial role in helping students to make the connections between their traditional coursework and the workplace. This study found that students place a great value on the internship experience. This is particularly true when the internship has a direct connection to their ultimate career goals. The perceived value of the internship is also related to the pedagogical approach and the demographic profile of the student. The value of the internship will be maximized if educators can provide the appropriate structure and integrate the experience with the academic background of the student. This approach will help to address the criticisms of business schools as being overly theoretical and abstract. It is clear that students appreciate the benefits of internship programs, particularly when designed to meet their needs. These programs should be a key element of business education in the $21^{\text {st }}$ century.

\section{AUTHOR INFORMATION}

Michael Hergert is a Professor of Management at San Diego State University. Dr. Hergert served as Dean of the College of Business at SDSU from 1997-2002.

Professor Hergert's teaching and research interests are in strategic management, industry economics, and international business. He is the author of over 25 published articles and one book, Surviving Merger and Acquisition, with Michael McManus. Prior to coming to SDSU, Professor Hergert received his Masters and Ph.D. in Business Economics from Harvard University and taught at UCLA and the INSEAD Business School in Fontainebleau, France.

Professor Hergert has worked as a Consultant with McKinsey and Company in Duesseldorf, Germany and was Director of Strategic Planning Applications at Data Resources, Inc. in Lexington, MA. At DRI, he developed a series of computer simulation models to forecast company and industry profitability and to simulate the financial impacts of alternative operating policies. His work at DRI received the McGraw Hill prize for best new business venture.

\section{REFERENCES}

1. Angelidis, J., Tomic, I., Ibrahim, N. Service learning projects enhance student learning in strategic management courses, Review of Business, 25, 32-36.

2. Bloom, B. (1956), Taxonomy of educational objectives: the classification of educational goals. Handbook 1: cognitive domain, New York: McKay.

3. Brooks, L., Cornelius, A., Greenfield, E., Joseph, R. (1995), The relation of career-related work or internship experiences to the career development of college seniors, Journal of Vocational Behavior, 46, 332-49.

4. Callanan, G., Benzing, C. (2004) Assessing the role of internships in the career-oriented employment of graduating college students, Education + Training, 46, 82-89.

5. Candy, P., Crebert, R. (1991) Ivory tower to concrete jungle, Journal of Higher Education, 62, 570-592.

6. Coco, M. (2000) Internships: A try before you buy arrangement. SAM Advanced Management Journal, 65, 41-43.

7. Gault, J., Redingtion, J., Schlager, T. (2000), Undergraduate business internships and career success: are they related?, Journal of Marketing Education, 22, 45-53.

8. Garavan, T., Murphy, C. (2001), The co-operative education process and organizational socialization: a qualitative study of student perceptions of its effectiveness, Education + Training, 43, 281-302.

9. Knouse, S., Tanner, J., Harris, E. (1999) The relation of college internships, college performance, and subsequent job opportunity, Journal of Employment Counseling, 36, 35-43.

10. Knemeyer, A., Murphy, P. (2002), Logistics internships: employer and student perspectives, International Journal of Physical Distribution and Logistics Management, 32, 135-152.

11. Maskooki, K., Rama, D., \& Raghunandan, K. (1998) Internships in undergraduate finance programs, Financial Practice and Education, Fall/Winter, 74-82. 
12. Paulson, S., Baker, H. (1999), An experimental approach to facilitate anticipatory socialization, The International Journal of Organizational Analysis, 7, 365-78.

13. Pedro, J. (1984), Induction into the workplace: the impact of internships, Journal of Vocational Behavior, 25, 80-95.

14. Porter, L., McKibbin, L. (1988), Management Education and Development: Drift or Thrust into the $21^{\text {st }}$ Century. New York: McGraw-Hill.

15. Richards, E. (1984), Undergraduate preparation and early career outcomes: a study of recent college graduates, Journal of Vocational Behavior, 24, 279-304.

16. Rothman, M. (2007), Lessons learned: advice to employers from interns, Journal of Education for Business, January/February, 140- 144. 
NOTES 